\title{
Group II mGlu Receptor Activation Suppresses Norepinephrine Release in the Ventral Hippocampus and Locomotor Responses to Acute Ketamine Challenge
}

\author{
Daniel S Lorrain*, ${ }^{*, 2}$, Hervé Schaffhauser ${ }^{1,2}$, Una C Campbell', Christopher S Baccei', Lucia D Correa', \\ Blake Rowe', Dana E Rodriguez', Jeffery J Anderson', Mark A Varney', Anthony B Pinkerton', Jean-Michel \\ Vernier' and Linda J Bristow' \\ 'Department of Neuropharmacology, Merck Research Laboratories, San Diego, CA, USA
}

\begin{abstract}
Group II mGlu receptor agonists (eg LY379268 and LY354740) have been shown to reverse many of the behavioral responses to PCP as well as glutamate release elicited by PCP and ketamine. In the present set of experiments, we used in vivo microdialysis to show that, in addition to reversing PCP- and ketamine-evoked glutamate release, group II mGlu receptor stimulation also prevents ketamine-evoked norepinephrine (NE) release. Pretreating animals with the mixed 2/3 metabotropic glutamate (mGlu2/3) receptor agonist LY379268 $(0.3-10 \mathrm{mg} / \mathrm{kg})$ dose-dependently inhibited ketamine $(25 \mathrm{mg} / \mathrm{kg})$-evoked NE release in the ventral hippocampus (VHipp). Ketamine hyperactivity was also reduced in a similar dose range. Following our initial observation on NE release, we conducted a series of microinjection experiments to reveal that the inhibitory effects of LY379268 on VHipp NE release may be linked to glutamate transmission within the medial prefrontal cortex. Finally, we were able to mimic the inhibitory effects of LY379268 on ketamine-evoked NE release by using a novel mGlu2 receptor selective positive modulator. (+ / ) 2,2,2-Trifluoroethyl [3-( I-methyl-butoxy)-phenyl]pyridin-3-ylmethyl-sulfonamide (2,2,2-TEMPS, characterized through in vitro GTP $\gamma S$ binding) at a dose of $100 \mathrm{mg} / \mathrm{kg}$ significantly reduced the NE response. Together, these results demonstrate a novel means to suppress noradrenergic neurotransmission (ie by activating mGlu2 receptors) and may, therefore, have important implications for neuropsychiatric disorders in which aberrant activation of the noradrenergic system is thought to be involved.

Neuropsychopharmacology (2003) 28, 1622- 1632, advance online publication, 25 June 2003; doi: 10.1038/sj.npp. 1300238
\end{abstract}

Keywords: microdialysis; metabotropic glutamate receptors; norepinephrine; schizophrenia; neurotransmitter release; allosteric modulator

\section{INTRODUCTION}

Ketamine and phencyclidine (PCP) administered to humans produce symptoms common to schizophrenia (Javitt and Zukin, 1991) and have been used in rodents to model the behavioral and neurochemical abnormalities associated with schizophrenia. Upon acute challenge, ketamine and/ or PCP activates limbic forebrain release of dopamine (DA) (Svensson, 2000), serotonin (5-HT) (Lindefors et al, 1997; Martin et al, 1998), norepinephrine (NE) (Kubota et al, 1999a, b), and glutamate (Moghaddam et al, 1997; Moghaddam and Adams, 1998; Adams and Moghaddam, 2001;

* Correspondence: Dr DS Lorrain, Merck Research Laboratories, 3535 General Atomics Court, San Diego, CA 92 I21, USA, Tel: + I 858202 5217, Fax: + I 858202 58|3, E-mail: Daniel_lorrain@merck.com 'Both authors participated equally to the study.

Received 28 February 2003; revised 28 April 2003; accepted 02 May 2003

Online publication: I5 May 2003 at http://www.acnp.org/citations/ Npp05 I503088/default.pdf
Lorrain et al, 2003) while decreasing the release of GABA (Yonezawa et al, 1998).

It is not clear which (if any) of these responses underlie the behavioral aberrations caused by these drugs. Recent findings, however, have highlighted the importance of glutamate neurotransmission. Pretreating animals with a mixed 2/3 metabotropic glutamate (mGlu2/3) receptor agonist (LY354740 or LY379268 (Monn et al, 1999)) prevented PCP and ketamine-evoked glutamate release, respectively, and LY354740 reversed the behavioral effects of PCP (Moghaddam and Adams, 1998; Cartmell et al, 1999; Lorrain et al, 2003).

In addition to blocking forebrain glutamate release, LY354740 has also been shown to inhibit the firing of neurons within the locus coeruleus (LC) (Vandergriff and Rasmussen, 1999) and thus may reduce NE release in terminal regions. Importantly, clinical evidence exists linking a hyperactive noradrenergic system to the pathophysiology of schizophrenia (Baldessarini et al, 1992). Firstly, atypical antipsychotics have a broad spectrum of activities including $\alpha$-adrenergic antagonistic properties 
(Schotte et al, 1996). Secondly, NE levels have been shown to be elevated in cerebral spinal fluid and plasma of drugfree patients (Lake et al, 1980; Breier et al, 1990; van Kammen et al, 1990), while post-mortem evidence revealed an increase of NE in brain tissue taken from schizophrenic patients (Farley et al, 1978; Crow et al, 1979). Finally, blockade of $\alpha$-adrenergic receptors in rodents has been shown to inhibit the motor-stimulant effects of NMDA antagonists (Mathe et al, 1996) while also preventing the disruption of prepulse inhibition (Bakshi and Geyer, 1997, 1999). Together, these data suggest that decreasing noradrenergic neurotransmission may be beneficial for improving clinical outcome in schizophrenia.

In the present study, we used microdialysis to show that, in addition to reversing ketamine-evoked glutamate release, the mGlu2/3 receptor agonist LY379268 also reduces ketamine-evoked NE release. Similarly, ketamine hyperactivity was reduced by LY379268. As our earlier findings showed that LY379268 could inhibit glutamate release (Lorrain et al, 2003), we tested here whether ketamineevoked NE release is indeed glutamate dependent. Through a series of microinjection experiments, we provide evidence that the group II effect on NE release may be a downstream consequence of reduced glutamate transmission within the medial prefrontal cortex. Finally, the mGlu2/3 receptor agonist effect on ventral hippocampus (VHipp) NE was mimicked by treating animals with an mGlu2 receptor selective potentiator (+I-) 2,2,2-Trifluoroethyl [3-(1methyl-butoxy)-phenyl]-pyridin-3-ylmethyl-sulfonamide (2,2,2-TEMPS).

\section{MATERIALS AND METHODS}

\section{Subjects}

Male Sprague-Dawley rats (250-300 g) were purchased from Harlan (San Diego, CA) and were used for all microdialysis and locomotor experiments; Wistar rats (2-4 weeks old) were purchased from Harlan (Indianapolis, IN) and were used for in vitro characterization of 2,2,2-TEMPS. All animals were maintained under a $12 \mathrm{~h}$ light/dark cycle with lights on at 0630 and off at 1830. All microdialysis and behavioral experiments occurred during the light phase of the light/dark cycle. All procedures were performed in accordance with The Guide for the Care and Use of Laboratory Animals and were approved by the Institutional Animal Care and Use Committee. Before and after surgeries, rats were allowed free access to standard rat chow and water. Temperature and relative humidity were maintained at $22-24^{\circ} \mathrm{C}$ and $50-55 \%$, respectively.

\section{Materials}

Ketamine (in the form of Ketaset, $100 \mathrm{mg} / \mathrm{ml}$ ) was obtained from Fort Dodge Animal Health (Fort Dodge, Iowa). LY379268 and 2,2,2-TEMPS were synthesized in house (Merck Research Laboratories, San Diego). LY341495 and CNQX were purchased from TOCRIS (Ellisville, MO). Glutamate, guanosine $5^{\prime}$-diphosphate (GDP), probenecid, and guanosine $5^{\prime}[\gamma$-thio]triphosphate $(\mathrm{GTP} \gamma \mathrm{S})$, were obtained from Sigma Chemical (St Louis, MO). $\left[{ }^{35} \mathrm{~S}\right] \mathrm{GTP} \gamma \mathrm{S}$ $(1250 \mathrm{Ci} / \mathrm{mmol})$, and Unifilter $\mathrm{GF} / \mathrm{B}$ plates and Microscint
20 were purchased from Perkin-Elmer Life Science (Boston, MA).

\section{Intracranial Implants}

Under $3 \%$ isoflurane (in $1 \% \mathrm{O}_{2}$ ) anesthesia, rats were implanted with a unilateral microdialysis probe CMA/11 with a $3 \mathrm{~mm}$ dialysis tip in the VHipp (anteroposterior, $-5.3 \mathrm{~mm}$; mediolateral, $-4.6 \mathrm{~mm}$; and dorsoventral, $-7.5 \mathrm{~mm}$ ) (Paxinos and Watson, 1998). The microdialysis probe was slowly lowered into position and was then fixed to the skull by means of three anchoring screws and application of dental acrylic. For microinjection experiments, in addition to a VHipp microdialysis probe, animals received a CMA/7 guide cannula aimed at either the MPFC (anteroposterior, $+3.2 \mathrm{~mm}$; mediolateral, $-0.7 \mathrm{~mm}$; and dorsoventral, $-4.0 \mathrm{~mm}$ ) or lateral ventricle (anteroposterior, $-0.8 \mathrm{~mm}$; mediolateral, $+1.4 \mathrm{~mm}$; and dorsoventral, $-3.0 \mathrm{~mm}$ ). Immediately following surgery, rats were placed in their testing arena and allowed to recover for a minimum of $14 \mathrm{~h}$.

\section{In Vivo Microdialysis and Chromatography}

For all microdialysis experiments, rats were tethered to a CMA awake animal system by means of a plastic collar (CMA Microdialysis, Acton, MA). All fluid connections were made using FEP tubing (internal volume of $1.2 \mu \mathrm{l}$ / $100 \mathrm{~mm}, \mathrm{CMA})$. Following the appropriate postsurgery recovery period $(\sim 0014$ hours $=\sim 0700$ hours $)$, perfusion through the dialysis probe with artificial cerebral spinal fluid (aCSF; $145 \mathrm{mM} \mathrm{NaCl} ; 2.7 \mathrm{mM} \mathrm{KCl} ; 1.0 \mathrm{mM} \mathrm{MgCl}_{2}$; and $1.2 \mathrm{mM} \mathrm{CaCl}$; $\mathrm{pH} 7.4$ ) was increased and maintained at $3.0 \mu \mathrm{l} / \mathrm{min}$. A 2 -h stabilization period was then allowed prior to sample collection. Fractions were collected at 20-min intervals $(60 \mu \mathrm{l})$ in $250 \mu \mathrm{l}$ glass vials via a BAS honeycomb fraction collector maintained at $4{ }^{\circ} \mathrm{C}$ (BAS HoneyComb; BAS, West Lafayette, IA). Samples were subsequently analyzed for neurotransmitter content by HPLC (see details below) within a 24 -h period.

NE, 5-HT, and HVA were assayed by HPLC coupled to electrochemical detection. Samples were loaded into an ESA autosampler (model 465), separated on a C18 reverse phase column (Phenomenex Luna, $150 \times 2.0 \mathrm{~mm}, 3 \mu \mathrm{m}$ particles) and detected by an ESA Coulochem controller unit using a model 5041 microdialysis analytical cell fitted with a glassy carbon electrode set to oxidize at $+250 \mathrm{mV}$. The mobile phase used was a phosphate buffer purchased from ESA (MD-TM). The rate of mobile phase flow through the system was $0.2 \mathrm{ml} / \mathrm{min}$. NE, HVA, and $5-\mathrm{HT}$ eluted with a retention time of approximately 4.5, 10, and $16 \mathrm{~min}$, respectively, under these isocratic conditions.

\section{Histology}

At the completion of each experiment, rats were euthanized by $\mathrm{CO}_{2}$ inhalation and their probes perfused with approximately $200 \mu \mathrm{l}$ of cresyl-violet dye. Animals implanted with a guide cannula received approximately 5-10 $\mu$ l of dye delivered to the brain via the microinjection cannula. Brains were then removed and either a single (probe-only animals) or double (probe + guide cannula animals) coronal 
cut was made at the level where the probe (or guide cannula) penetrated the cortex. The resulting coronal section(s) was/were placed onto a glass slide and an image scanned into a personal computer using an HP ScanJet 7400L scanner. Only those animals demonstrating dye within the appropriate regions of the brain were included in the results.

\section{Inhibition of Stimulant-Induced Hyperactivity}

In order to evaluate the effects of LY379268, rats were habituated to individual activity chambers (Med Associates Inc., Georgia, VT) for $60 \mathrm{~min}$. Following habituation, subjects were injected with LY379268 $(0.3-10 \mathrm{mg} / \mathrm{kg})$ or vehicle and returned to the chambers. After a 30-min pretreatment period, rats were dosed with either vehicle or ketamine $(25 \mathrm{mg} / \mathrm{kg})$, and activity was recorded in $10 \mathrm{~min}$ intervals for $120 \mathrm{~min}$. Antagonist experiments using the selective mGlu2/3 antagonist, LY341495, involved coinjecting LY341495 (1 mg/kg) with LY379268 (3 mg/kg) or vehicle.

\section{Administration of Drugs}

For systemic administration, drugs were prepared in saline ( $\mathrm{pH}$ adjusted to 7.0) with the exception of 2,2,2-TEMPS, which was dissolved in a $50 \%$ polyethylene glycol solution. All drugs were delivered subcutaneously (s.c.) in a volume of $1 \mathrm{ml} / \mathrm{kg}$. All experiments had appropriate vehicle controls. For central administration, drugs were prepared in aCSF ( $\mathrm{pH}$ adjusted to 7.4). Local delivery of LY379268 to the VHipp was accomplished via the microdialysis probe by manually switching the inlet tubing from a syringe containing aCSF to one containing a $1 \mathrm{mM}$ concentration of drug. For the mPFC microinjection experiment, the drug was delivered via a CMA microinfusion pump in a volume of $1 \mu \mathrm{l}$ over a 2 -min period. For the intracerebral ventricular (i.c.v.) experiment, the drug was delivered in a $10 \mu$ l volume at a rate of $2 \mu \mathrm{l} / \mathrm{min}$. In both cases, this was accomplished by removing the obturator from the guide cannula and inserting a microinjection cannula without removing the animals from their testing environment.

\section{Membrane Preparation and $\left[{ }^{35} S\right]$ GTP $\gamma S$ Binding}

hmGlu2 and hmGlu3 receptor-expressing stable cell lines (Varney et al, 1999) were grown to $80-90 \%$ confluency in T$225 \mathrm{~cm}^{2}$ flasks and washed twice with ice-cold PBS. The cells were then scraped with a cell scraper in PBS and harvested by centrifugation $(200 \mathrm{~g})$. The cell pellet was homogenized in buffer A containing HEPES $(20 \mathrm{mM})$, EDTA $(10 \mathrm{mM})$, $\mathrm{pH}=7.4$ using a Polytron (Brinkmann Instruments, Westbury, NY). The homogenate was centrifuged at $40000 \mathrm{~g}$ for $20 \mathrm{~min}$. The resulting pellet was washed once in the same buffer and once with buffer B containing HEPES (20 mM) and EDTA $(0.1 \mathrm{mM}) \mathrm{pH}=7.4$. At the last centrifugation, the pellet was resuspended in buffer $\mathrm{B}$ and the homogenate was aliquoted and stored at $-80^{\circ} \mathrm{C}$ at a protein concentration of approximately $1 \mathrm{mg} / \mathrm{ml}$. Protein measurement was determined with the Bio-Rad DC kit (Bio-Rad, Hercules, CA) using bovine serum albumin as standard.

Whole rat brain membranes were prepared. Rats (250$300 \mathrm{~g}$ ) were decapitated and the whole brain removed on ice and homogenized in $6 \mathrm{vol}(\mathrm{w} / \mathrm{v})$ of $10 \%$ sucrose at $4{ }^{\circ} \mathrm{C}$ using a glass-Teflon homogenizer. The homogenate was centrifuged at $1000 \mathrm{~g}$ for $10 \mathrm{~min}$, and the supernatant was centrifuged at $40000 \mathrm{~g}$ for $20 \mathrm{~min}$. The pellet was resuspended in $25 \mathrm{ml}$ water using a Polytron homogenizer and centrifuged at $8000 \mathrm{~g}$ for $10 \mathrm{~min}$. The supernatant was further centrifuged at $40000 \mathrm{~g}$ for $20 \mathrm{~min}$ at $4{ }^{\circ} \mathrm{C}$. The supernatant was removed and the pellet was resuspended in buffer $\mathrm{C}$ containing HEPES ( $5 \mathrm{mM})-\mathrm{KOH} \mathrm{pH}=7.4)$. The homogenate was freeze-thawed twice before being centrifuged at $40000 \mathrm{~g}$ for $20 \mathrm{~min}$. Finally, the resulting pellet was resuspended in buffer $\mathrm{C}$, aliquoted, and stored at $-70^{\circ} \mathrm{C}$ until use.

\section{$\left[{ }^{35} \mathrm{~S}\right]$ GTP $\gamma \mathrm{S}$ Binding Assay}

Membranes from stably transfected cells or from rat brain were thawed and homogenized in $25 \mathrm{ml}$ of buffer B, and centrifuged at $40000 \mathrm{~g}$ for $20 \mathrm{~min}$. The pellet was resuspended in assay buffer containing HEPES (20 mM) (pH 7.4), $\mathrm{NaCl}(100 \mathrm{mM}), \mathrm{MgCl}_{2}(3 \mathrm{mM})$ at a final protein concentration of $0.5 \mathrm{mg} / \mathrm{ml}$ (hmGlu2 and hmGlu3 receptors) or $0.1 \mathrm{mg} / \mathrm{ml}$ (rat brain). In a Beckmann 96-well plate, test compounds were added along with GDP $(5 \mu \mathrm{M})$, membrane $(10 \mu \mathrm{g} /$ well for rat brain and $50 \mu \mathrm{g}$ for recombinant $\mathrm{mGlu}$ receptors), $\left[{ }^{35} \mathrm{~S}\right] \mathrm{GTP} \gamma \mathrm{S}(0.05 \mathrm{nM})$ to achieve a total volume of $0.5 \mathrm{ml}$ in assay buffer. The plate was incubated at $30^{\circ} \mathrm{C}$ for $1 \mathrm{~h}$ and the assay was terminated by rapid filtration over Unifilter GF/B plate using a 96-well cell harvester (Brandel Gaithersburg, MD). The plate was rinsed three times with ice-cold assay buffer, dried and $50 \mu \mathrm{l}$ of Microscint 20 was added to each well. The plate was counted in a Topcount scintillation counter (Perkin-Elmer, Boston MA).

Nonspecific binding was determined by addition of $10 \mu \mathrm{M}$ unlabeled GTP $\gamma$ S. Each experiment was performed using triplicate samples per data point and then repeated on separate occasions to obtain a total of three determinations. Data were normalized to the maximal response obtained with $1 \mathrm{mM}$ glutamate. The curves were fitted to a fourparameter logistic equation giving $\mathrm{EC}_{50}$ values, Hill coefficient and maximal effect using Prism (GraphPad Software, San Diego, CA).

\section{Effect of 2,2,2-TEMPS on hmGlu5a and hmGlu7a Receptors}

The activity of 2,2,2-TEMPS was examined against hmGlu5a or hmGlu7a receptors stably expressed in mouse fibroblast Ltk cells or CHO cells, respectively. To couple the activation of hmGlu7a receptors to changes in $\left[\mathrm{Ca}^{2+}\right]_{\mathrm{i}} \mathrm{hmGlu}$ a was stably expressed with $\mathrm{G} \alpha 16$. Receptor activity was detected by changes in $\left[\mathrm{Ca}^{2+}\right]_{i}$, measured using the fluorescent $\mathrm{Ca}^{2+}$-sensitive dye Fura-2 as previously described by Varney et al (1999) for mGlu5 activity or Fluo-3 on a VIPR-2 (Aurora Biosystems) for mGlu7 activity. For antagonist testing, a submaximal concentration of glutamate was used $(10 \mu \mathrm{M}$ and $2 \mathrm{mM}$ for hmGlu5 and hmGlu7 receptor, respectively).

\section{Data Analysis}

Dialysis data collected and analyzed were not corrected for in vitro probe recovery. Time course data represent the 
percent change from baseline (calculated by taking the average of two pretreatment samples). Summary data represent the raw area under each 120-min time course curve. Data were then subject to either a simple betweensubjects $t$-test or to a one-factor ANOVA. Post hoc analyses were carried out using Dunnett's (for comparison to a single control group) or Student-Newman-Keuls tests (for all pairwise comparisons). Activity data (total distance traveled) represent the group mean ( \pm SEM) recorded for the total duration of the 120-min test period. Data were analyzed by one-factor ANOVA followed by Dunnett's or Student-Newman-Keuls tests.

\section{RESULTS}

\section{Group II mGlu Receptor Modulation of Ketamine- Evoked NE Release}

Systemic administration of ketamine $(12.5-50 \mathrm{mg} / \mathrm{kg}$, s.c.) resulted in a dose-dependent increase in hippocampal $\mathrm{NE}$ release $(F(3,13)=42.3, P<0.001$; Figure $1 \mathrm{a}, \mathrm{b})$. Dunnett's post hoc comparisons revealed a significantly greater area under the curve in dialysates from animals treated with 25 and $50 \mathrm{mg} / \mathrm{kg}$ ketamine compared to vehicle controls $(P<0.05)$. Pretreating animals with the mGlu2/3 receptor agonist LY379268 $(0.3-10 \mathrm{mg} / \mathrm{kg}$, s.c.) inhibited ketamineevoked NE release in a dose-dependent fashion $(\mathrm{F}(3,21)=15.9, P<0.001$; Figure 1c, d). Dunnett's post hoc comparisons revealed significant inhibition with 3 and $10 \mathrm{mg} / \mathrm{kg}$ LY379268 compared to vehicle controls $(P<0.05)$. This effect of LY379268 $(3 \mathrm{mg} / \mathrm{kg})$ was reversed by cotreating animals with the mGlu2/3 receptor antagonist LY341495 $(3 \mathrm{mg} / \mathrm{kg})(\mathrm{F}(3,19)=7.6, P<0.01$; Figure 1e,f). Consistent with the locomotor data (see below), administration of the antagonist LY34149 $(3 \mathrm{mg} / \mathrm{kg})$ alone produced a marked increase in ketamine-evoked NE release $(P<0.05)$. In a subset of animals, we tested whether the effect of LY379268 was selective for NE or whether it would generalize to all monoamine systems. Ketamine evoked a significant increase in both 5-HT and the DA metabolite HVA (DA itself was below detection limits in the dialysate collected). Pretreating animals with a high dose of LY379268 $(10 \mathrm{mg} / \mathrm{kg})$ failed to alter these responses. The ANOVA conducted on 5-HT revealed a significant overall effect of ketamine on 5 -HT release $(\mathrm{F}(2,9)=12.3, P<0.01$; Figure 2$)$. Using Student-Newman-Keuls post hoc comparisons, we observed a significant effect of ketamine on 5-HT with and without LY379268 $(P<0.05)$. No difference was observed between groups receiving ketamine alone $v s$ ketamine + LY379268. Similar to 5-HT, the ANOVA conducted on HVA revealed a significant overall effect of ketamine on HVA release $(\mathrm{F}(2,11)=11.8, P<0.01$; Figure 2). Again, like the 5-HT data, post hoc comparisons revealed a significant effect of ketamine on HVA regardless of pretreatment with LY379268 $(P<0.05)$. No difference was observed between groups receiving ketamine alone $v s$ ketamine + LY379268.

\section{Group II mGlu Receptor Modulation of Ketamine Hyperactivity}

Ketamine $(12.5-50 \mathrm{mg} / \mathrm{kg}$, s.c.) dose-dependently increased locomotor activity in habituated rats as shown by an increase in the total distance traveled $(\mathrm{F}(3,28)=14.15$, $P<0.001$; Figure 3a). Dunnett's post hoc analyses indicated a significant hyperactivity response following administration of 25 and $50 \mathrm{mg} / \mathrm{kg}$ of ketamine compared to vehicle-treated animals $(P<0.05)$. Acute administration of LY379268 $(0.3-10 \mathrm{mg} / \mathrm{kg}$, s.c.) dose-dependently suppressed ketamine $(25 \mathrm{mg} / \mathrm{kg}$, s.c.)-induced hyperactivity $(\mathrm{F}(5,82)=33.09, \quad P<0.001$; Figure $3 \mathrm{~b})$. Post hoc testing revealed a significant inhibition of the ketamine hyperactivity response following administration of 1,3 , and $10 \mathrm{mg} / \mathrm{kg}$ of LY379268 $(P<0.05)$. The inhibition of ketamine $(25 \mathrm{mg} / \mathrm{kg}$, s.c.) hyperactivity responses by LY379268 (3 mg/kg, s.c.) was reversed following the administration of LY341495 (1 mg/kg, s.c.). LY341495 $(1 \mathrm{mg} / \mathrm{kg})$ was also found to significantly potentiate the hyperactivity response induced by ketamine $(\mathrm{F}(5,42)=25.84, P<0.001$; Figure $3 \mathrm{c})$.

\section{Modulation of Ketamine-Evoked NE Release by Central Administration of LY379268 and CNQX}

As our earlier findings convincingly showed that LY379268 could inhibit glutamate release (Lorrain et al, 2003), we questioned whether ketamine-evoked $\mathrm{NE}$ release is indeed glutamate dependent. To test this, we delivered the AMPA/ kainate antagonist CNQX (15 nmol, i.c.v.) prior to systemic ketamine injection and compared this effect to that seen after i.c.v. LY379268 ( $1 \mathrm{nmol})$ pretreatment. The ANOVA conducted on the area under the curve data revealed a significant effect on NE release between treatment groups $(\mathrm{F}(2,13)=9.38, \quad P<0.01$; Table 1$)$. Dunnett's post hoc comparisons showed that NE release in both LY379268and CNQX-pretreated animals was significantly reduced compared to vehicle-treated controls $(P<0.05)$. Next we focused on identifying the site of action of LY379268. To accomplish this, LY379268 was microinjected into discrete brain regions; (1) the VHipp (accomplished by reverse dialyzing $1 \mathrm{mM}$ concentration of drug through the microdialysis probe) and (2) the mPFC (accomplished by microinjecting $0.1 \mathrm{nmol}$ of LY379268 via a microinjection cannulae). We observed no significant effect of LY379268 on ketamine-evoked NE release when delivered to VHipp $(t(9)=0.57, P=0.58$; Table 1$)$. When delivered directly to the $\mathrm{mPFC}$, on the other hand, we observed a significant inhibition by LY379268 on ketamine-evoked NE release $(t(8)=5.0, P<0.001$; Table 1). Importantly, we showed in a previous experiment that ketamine increases extracellular glutamate levels in the mPFC and that local delivery of LY379268 could block this glutamate response (Lorrain et al, 2003). Together with our current findings, we hypothesized that LY379268 inhibition of ketamine-evoked NE release is a direct downstream consequence of LY379268 inhibition of mPFC glutamate release.

Inhibition of Ketamine-Evoked NE Release by the mGlu2 Receptor Selective Positive Modulator 2,2,2TEMPS

In vitro characterization of 2,2,2-TEMPS. In the current experiment, we tested whether the effects of the mixed mGlu2/3 receptor agonist LY379268 could be mimicked by an mGlu2 receptor selective glutamate positive modulator. 

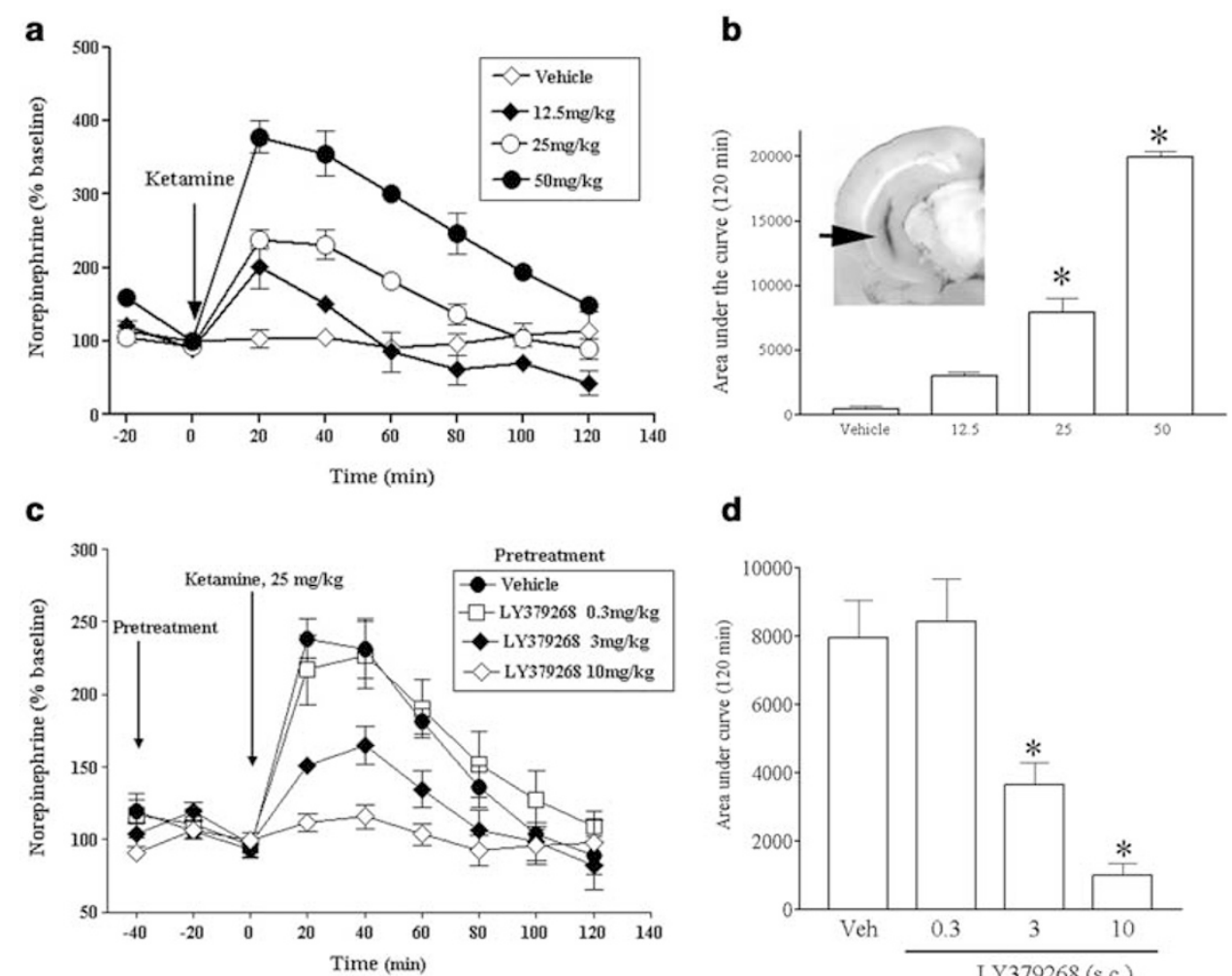

d

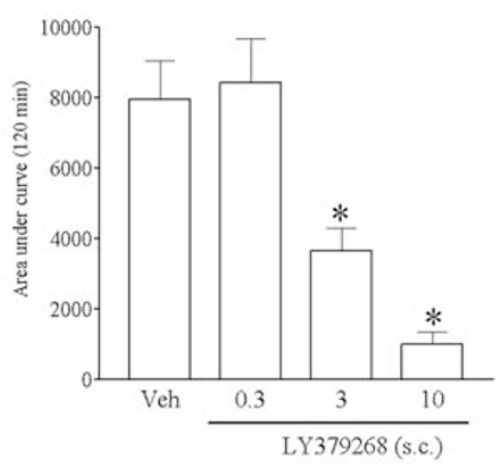

e

$\mathbf{f}$
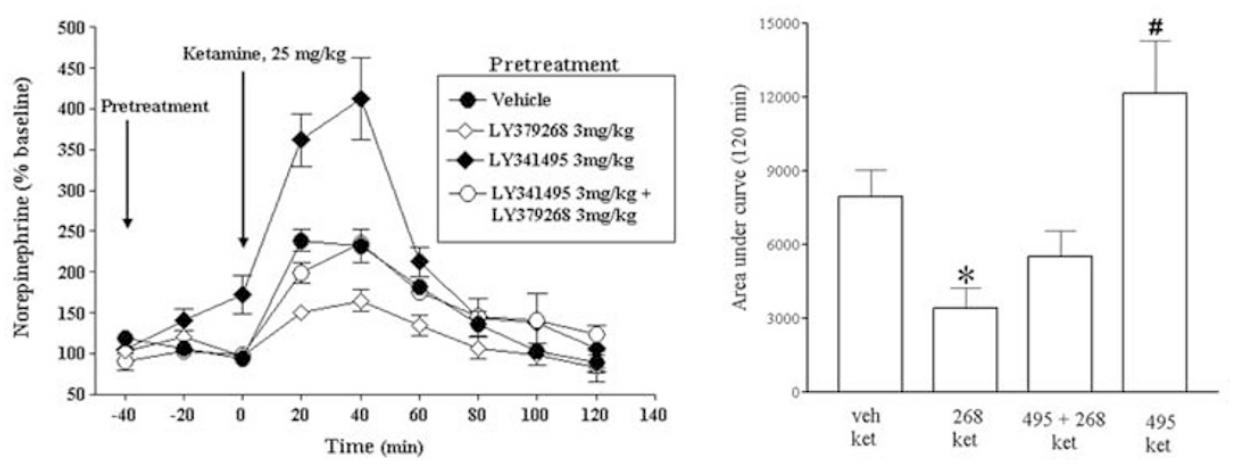

Figure I Modulation of ketamine-evoked NE release by the mGlu2/3 receptor agonist LY379268. (a, c, and e) Microdialysis time course data. (b, d, and f) Summary data showing the area under each 120-min time course curve. (b, inset) Representative coronal section showing the spread of dye from the active portion of the dialysis membrane to the surrounding tissue in an individual subject with an appropriately placed microdialysis probe. (a, b) Ketamine (I2.5$50 \mathrm{mg} / \mathrm{kg}$, s.c.) produced a dose-dependent increase in VHipp NE release. (c, d) LY379268 (0.3-10 mg/kg, s.c.) given 30 min prior to ketamine (25 mg/kg, s.c.) dose-dependently inhibited ketamine-evoked NE release. ( $d$, e) This effect was reversed by cotreatment with the group II mGlu receptor selective antagonist LY34 I 495 (3 mg/kg LY379268 + 3 mg/kg LY34 I 495). LY34I 495 alone significantly increased ketamine-evoked NE release. Data are expressed as mean \pm SEM. NE levels were estimated to be $15 \pm$ I fg/ $\mu$ l of sample; $n=3-7 /$ group. Data were analyzed by a one-way ANOVA followed by Dunnett's or Student-Newman-Keuls tests. ${ }^{*} P<0.05$ compared to vehicle/ketamine-treated rats. ${ }^{\#} P<0.05$ compared to vehicle/ketamine, LY379268/ketamine, and LY34|495 + LY379268/ketamine.

Prior to in vivo testing, we used $\left[{ }^{35} \mathrm{~S}\right] \mathrm{GTP} \gamma \mathrm{S}$ binding to demonstrate that 2,2,2-TEMPS is indeed a selective mGlu2 receptor potentiator. 2,2,2-TEMPS on its own did not stimulate $\left[{ }^{35} \mathrm{~S}\right] \mathrm{GTP} \gamma \mathrm{S}$ binding in membranes prepared from cells expressing hmGlu2 receptors, hmGlu3 receptors or rat brain (data not shown). However, in the presence of a low concentration of glutamate that evoked a small response (an approximate $\mathrm{EC}_{10}$ of $1 \mu \mathrm{M}$ for rat brain and hmGlu2 and $10 \mathrm{nM}$ for hmGlu3 receptors), 2,2,2-TEMPS increased the magnitude of the glutamate-induced $\left[{ }^{35} \mathrm{~S}\right] \mathrm{GTP} \gamma \mathrm{S}$ binding in a concentrationdependent manner. Interestingly, while the $\mathrm{EC}_{50}$ values for 2,2,2-TEMPS were similar under these conditions, the magnitude of the potentiation was four times higher in rat brain compared to hmGlu2 membranes (Figure 4a). In contrast, 2,2,2-TEMPS was without effect on glutamate-induced $\left[{ }^{35} \mathrm{~S}\right] \mathrm{GTP} \gamma \mathrm{S}$ binding in membranes prepared from cells expressing hmGlu3 receptors (Figure 4a).

Additionally, 2,2,2-TEMPS was tested for its ability to potentiate glutamate-stimulated responses in cell lines expressing human group I (hmGlu5) and group III (hmGlu7) mGlu receptors. 2,2,2-TEMPS was devoid of any agonist, antagonist, or allosteric modulator activities on these mGlu receptor subtypes (Table 2). 


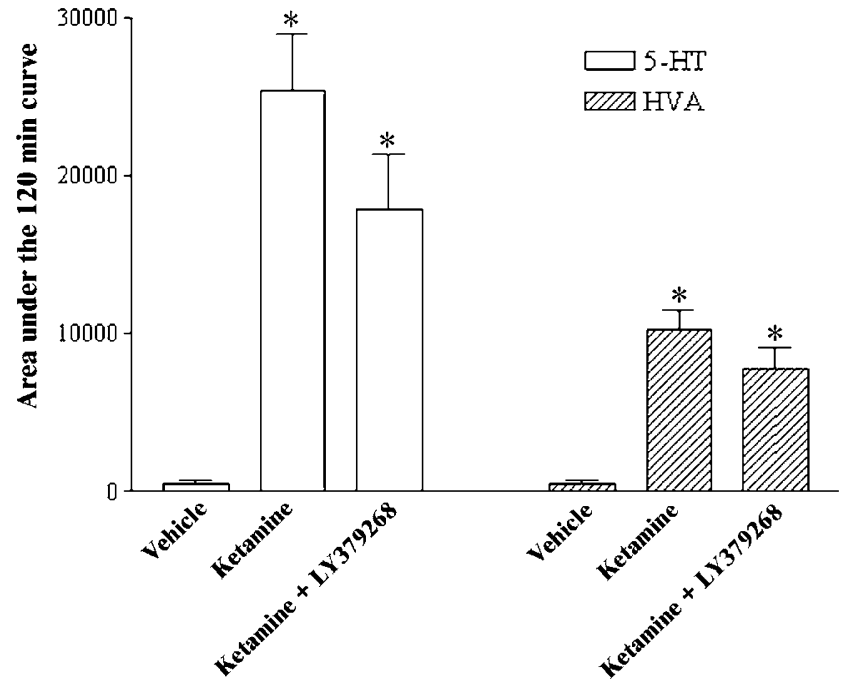

Figure 2 Effects of the mGlu2/3 receptor agonist LY379268 on ketamine (25 mg/kg, s.c.)-evoked 5-HT and HVA release. Unlike the NE response, neither $5-\mathrm{HT}$ nor HVA were significantly altered by pretreating animals with LY379268 (10 mg/kg, s.c.). Data (mean \pm SEM) are expressed as the area under each respective 120-min time course curve. 5-HT and HVA levels were estimated to be $4.9 \pm 0.9 \mathrm{fg} / \mu \mathrm{l}$ of sample and $244.9 \pm 24.9 \mathrm{fg} / \mu \mathrm{l}$ of sample, respectively; $n=3-6 /$ group. $* P<0.05$ vs vehicle control as revealed by one-factor ANOVA followed by Dunnett's post hoc comparisons.

In order to characterize the effect of this positive modulator further on mGlu2 receptors, concentrationresponse curves to glutamate were performed using $\left[{ }^{35} \mathrm{~S}\right] \mathrm{GTP} \gamma \mathrm{S}$ binding in the presence of a fixed concentration of 2,2,2-TEMPS $(3 \mu \mathrm{M})$. Under these conditions, 2,2,2TEMPS produced a 2.5 -fold increase in the apparent potency $\left(\mathrm{EC}_{50}\right)$ of glutamate and did not further increase the maximum response induced by glutamate on mGlu2 receptors (Table 3). Similar studies carried out in recombinant cell lines expressing hmGluR3 showed no change in either the $\mathrm{EC}_{50}$ or the $E_{\max }$ for glutamate-induced stimulation of $\left[{ }^{35} \mathrm{~S}\right] \mathrm{GTP} \gamma \mathrm{S}$ binding. These results suggest that 2,2,2TEMPS is a selective mGlu2 receptor positive modulator that increases both the affinity and the efficacy of an agonist ligand.

Effect of 2,2,2-TEMPS on ketamine-evoked NE release. Systemic administration of the mGlu2 receptor selective potentiator 2,2,2-TEMPS at a dose of $100 \mathrm{mg} / \mathrm{kg}$, s.c. significantly inhibited ketamine-evoked hippocampal NE release $(\mathrm{F}(2,24)=5.65, P<0.01$; Figure $4 \mathrm{~b}, \mathrm{c})$. This effect of 2,2,2-TEMPS was reversed by the selective mGlu2/3 receptor antagonist LY341495 (3 mg/kg, s.c.).

\section{DISCUSSION}

The present study demonstrates an important role for group II mGlu receptors in the modulation of ketamine-evoked NE release and ketamine hyperactivity. Upon acute challenge, ketamine increased extracellular levels of NE (as well as 5HT and HVA) in the VHipp. We chose this region because of earlier work showing strong activation of 2-deoxyglucose uptake in the hippocampus following systemic ketamine

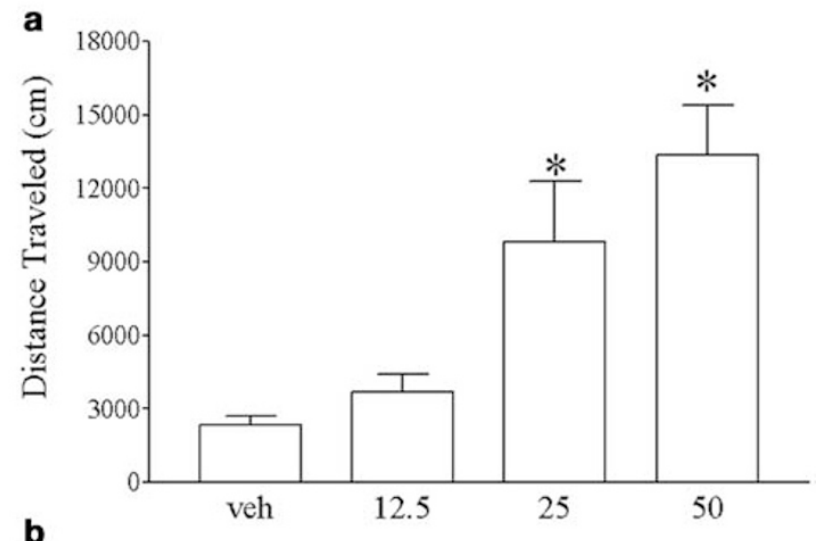

b
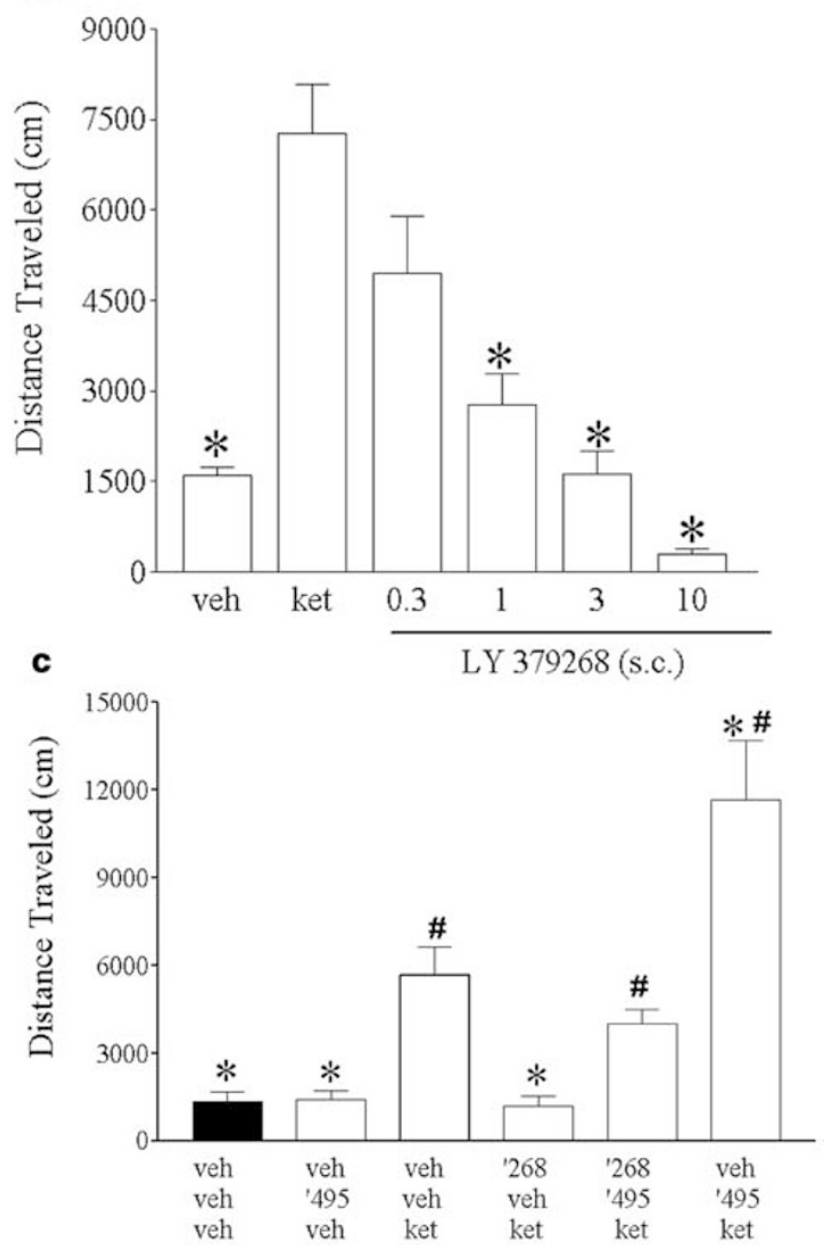

Figure 3 Modulation of ketamine hyperactivity by the $\mathrm{mGlu} 2 / 3$ receptor agonist LY379268. (a) Ketamine (12.5-50 mg/kg, s.c.) produced a dosedependent increase in locomotor activity. (b) LY379268 $(0.3-10 \mathrm{mg} / \mathrm{kg}$, s.c.) produced a dose-dependent suppression of ketamine ( $25 \mathrm{mg} / \mathrm{kg}$, s.c.)induced hyperactivity. (c) The inhibition of ketamine hyperactivity by LY379268 (3 mg/kg) was reversed by the $\mathrm{mGlu2} / 3$ receptor antagonist LY34|495 (I mg/kg). LY34|495 (I mg/kg) significantly potentiated ketamine-evoked hyperactivity. Subjects were dosed with LY379268 and/or LY34I495 or vehicle 30 min before receiving s.c. injections of ketamine. Activity data (total distance traveled) are presented as the group mean $( \pm \mathrm{SEM})$ recorded for the total duration of the $2 \mathrm{~h}$ test period. Data were analyzed by a one-way ANOVA followed by Dunnett's or StudentNewman-Keuls tests; *P $<0.05$ compared to (a) vehicle or (b) vehicle/ ketamine-treated animals; ${ }^{\#} P<0.05$ compared to LY379268/ ketaminetreated rats. 
Table I Effects of LY379268 and CNQX on Ketamine $(25 \mathrm{mg} / \mathrm{kg}$, s.c.)-Evoked NE Release when Administered in Discrete Brain Regions

\begin{tabular}{|c|c|c|c|c|}
\hline Brain region & Drug & Dose & AUC (n) & \% Inhibition \\
\hline i.c.v. & $\begin{array}{l}\text { Vehicle } \\
\text { CNQX } \\
\text { LY379268 }\end{array}$ & $\begin{array}{l}0 \mathrm{nmol} / / 0 \mu \mathrm{|} \\
\mid 5 \mathrm{nmol} / \mathrm{|O} \mu \mathrm{|} \\
|\mathrm{nmol} / \mathrm{|} 0 \mu|\end{array}$ & $\begin{array}{l}7951 \pm 1103(8) \\
2633 \pm 1072 *(3) \\
2045 \pm 692^{*}(4)\end{array}$ & $\begin{array}{c}0 \\
-67 \\
-75\end{array}$ \\
\hline VHipp & $\begin{array}{l}\text { Vehicle } \\
\text { LY379268 }\end{array}$ & $\begin{array}{l}0 \mathrm{mM} \\
1 \mathrm{mM}\end{array}$ & $\begin{array}{l}8073 \pm 1266(7) \\
7034 \pm 802(4)\end{array}$ & $\begin{array}{c}0 \\
-13\end{array}$ \\
\hline mPFC & $\begin{array}{l}\text { Vehicle } \\
\text { LY379268 }\end{array}$ & $\begin{array}{l}0 \mathrm{nmol} / \mid \mu \mathrm{l} \\
0 \mid \mathrm{nmol} / / \mu \mathrm{l}\end{array}$ & $\begin{array}{l}6127 \pm 922(5) \\
114 \mid \pm 342 *(5)\end{array}$ & $\begin{array}{c}0 \\
-81\end{array}$ \\
\hline
\end{tabular}

Drugs were either microinjected into the lateral ventricle (i.c.v.), ipsilateral medial prefrontal cortex (mPFC) or perfused directly into the ventral hippocampus (VHipp, via the microdialysis probe). i.c.v. Administration of both LY379268 and the AMPA/kainate antagonist CNQX inhibited ketamine-evoked NE (drug was given 30 min prior to ketamine). No effect was observed when LY379268 was applied directly to the VHipp via the microdialysis probe (drug perfusion was initiated 30 min prior to ketamine and continued throughout the 120 min collection period). Direct injection of LY379268 into the ipsilateral mPFC significantly inhibited ketamine-evoked NE (LY379268 was delivered 10 min prior to ketamine). Data (mean \pm SEM) are expressed as area under each respective I20-min time course $(A \cup C)$. *P $<0.05$ : Significant effect on AUC compared to vehicle control group as revealed by Dunnett's post hoc analysis following ANOVA or t-test.

injection (Duncan et al, 1999). Pretreating animals with a group II mGlu receptor agonist LY379268 prevented the increase in NE release while having no effect on either 5-HT or HVA. Coadministration of the selective mGlu2/3 receptor antagonist, LY341495, reversed the inhibitory effects of LY379268. LY341495 on its own enhanced ketamine-evoked NE release, an effect also noted in the ketamine hyperactivity tests. This is an important observation and suggests that endogenous glutamate acting on mGlu2/3 receptors partly suppresses NE release and locomotion under conditions of ketamine challenge. To our knowledge, these are the first in vivo microdialysis data providing direct evidence that group II mGlu receptors can selectively modulate NE release. These results are consistent with one earlier finding by Vandergriff and Rasmussen (1999), showing that LY354740, a selective but less potent mGlu2/ 3 receptor agonist (Schoepp et al, 1997; Monn et al, 1999), can attenuate morphine-withdrawal-induced activation of LC neurons.

We also demonstrate that the inhibition of ketamineevoked NE release following activation of group II mGlu receptors may be linked to reduced glutamate transmission within the mPFC. First we found that ketamine-evoked NE release was inhibited by i.c.v. administration of the AMPA/ kainate receptor antagonist $\mathrm{CNQX}$, suggesting that the ketamine response is dependent on glutamate transmission. In addition, i.c.v. administration of LY379268 diminished ketamine-evoked NE release, thus, establishing that the effect of LY379268 is centrally mediated. Next we showed that LY379268 blocked VHipp NE release when microinjected directly into ipsilateral $\mathrm{mPFC}$, but not when delivered directly to the VHipp. The mPFC was chosen for two reasons. Firstly, studies using $\left[{ }^{3} \mathrm{H}\right]-\mathrm{LY} 354740$ revealed a high density of specific binding throughout the cerebral cortex (Schaffhauser et al, 1998) and specifically within the mPFC (Marek et al, 2000, 2001). Secondly, we have recently shown that ketamine increases the release of glutamate within the MPFC and that perfusing LY379268 directly to the $\mathrm{mPFC}$ reduced local glutamate release elicited by systemic ketamine, presumably through presynaptic inhibi- tion (Lorrain et al, 2003). As neuronal pathways exist linking the mPFC to the LC (Takagishi and Chiba, 1991; Buchanan et al, 1994), it is likely that prefrontal glutamate may drive LC activity and hence NE release. Therefore, preventing glutamate release in the prefrontal cortex, as in the case with LY379268, may prevent efferent activation of LC and subsequent NE release. This would explain our current findings. If true, we should expect to see an effect of a group II mGlu receptor agonist on LC firing and in fact this has been observed (Dube and Marshall, 1997; Vandergriff and Rasmussen, 1999). In addition, if LY379268 is mediating its effects on NE release through inhibition of LC activity, then we predict a global effect on $\mathrm{NE}$ release throughout the forebrain that is not limited to the VHipp. Preliminary experiments from our laboratory support such a model. We cannot, however, rule out a direct connection from the mPFC to the VHipp in mediating the LY379268 effect.

In a manner consistent with the microdialysis data, LY379268 inhibited ketamine-evoked locomotion; an effect that was also reversed by LY341495. Although we cannot convincingly conclude a causal link between NE release and locomotion from the current study, previous reports do support such a relationship. For example, intraventricular injection of NE produced an increase in locomotor activity of rats (Segal and Mandell, 1970). More importantly, locomotor activity increased when NE was microinjected directly into the hippocampus (Flicker and Geyer, 1982). Finally, blockade of $\alpha$-adrenergic receptors in rodents has been shown to inhibit the motor-stimulant effects of NMDA antagonists (Mathe et al, 1996). It will be important to know whether ketamine hyperactivity can similarly be inhibited by direct infusion of an $\alpha$-adrenergic antagonist to the hippocampus.

Finally, we tested whether our effects of LY379268 on NE release and locomotion could be reproduced using an mGlu2 receptor selective ligand. For this purpose we selected 2,2,2-TEMPS, a positive allosteric modulator of the mGlu2 receptor previously reported to produce in vivo behavioral effects similar to those produced by mGlu2/3 


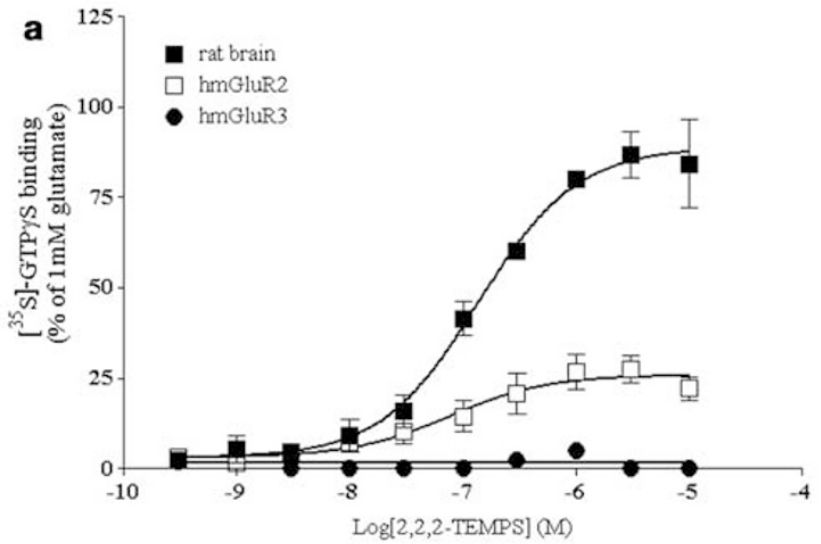

b

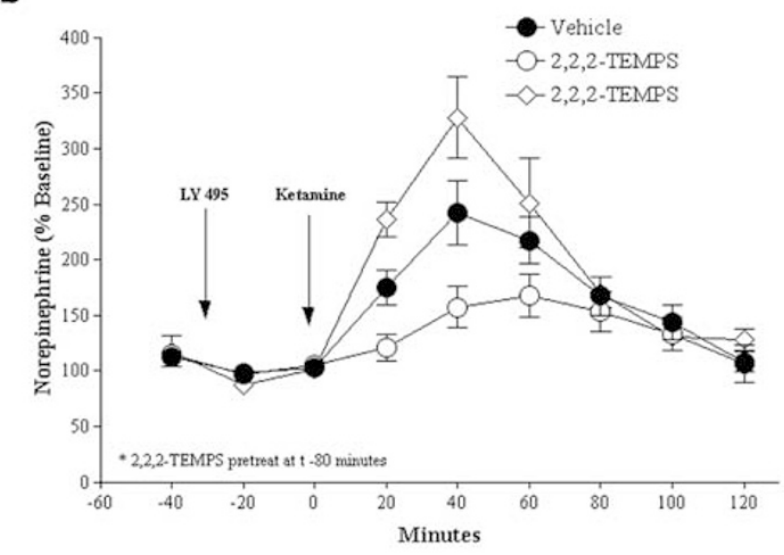

c

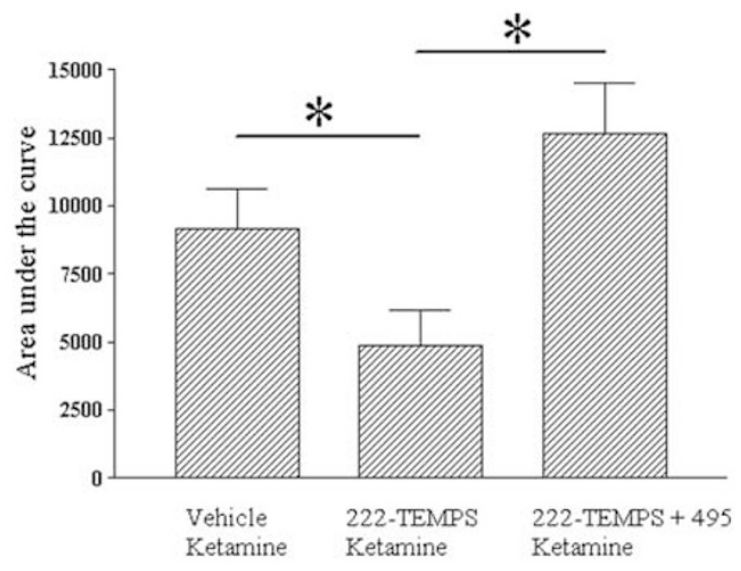

Figure 4 In vitro and in vivo effects of the mGlu2 selective modulator 2,2,2-TEMPS. (a) Stimulation of $\left[{ }^{35} \mathrm{~S}\right] \mathrm{GTP} \gamma \mathrm{S}$ binding by $2,2,2$-TEMPS in the presence of glutamate $\left(E C_{10}\right)$ in membranes from rat brain or cell lines stably expressing hmGlu2 or hmGlu3 receptors. Results are expressed as the percentage of the maximal stimulation induced by glutamate $(\mathrm{I} \mathrm{mM})$ alone and are the means of three individual experiments performed in triplicate. Rat brain cortex $E_{50}(n M)=135$ (range: 125-144), $E_{\max }=88 \pm 8 ;$ hmGluR2 $\mathrm{EC}_{50}(\mathrm{nM})=80$ (range: 50-114), $E_{\max }=23 \pm 2$; 2; no effects observed at hmGluR3. (b, c) Systemic administration of 2,2,2TEMPS (100 mg/kg, s.c.) reduced ketamine-evoked NE release in the rat VHipp and this effect was reversed by the group II antagonist LY34I495 (3 mg/kg, s.c); $n=5-1$ I/group. (b) Time course of the effect. (c) Summary data illustrating the area under each 120-min time course curve. The summary microdialysis data were analyzed by ANOVA followed by Student-Newman-Keuls post hoc comparisons. $* P<0.05$ compared to vehicle/ketamine and LY34I495 + 2,2,2-TEMPS/ketamine-treated rats.
Table 2 Test of any Potentiator, Agonist, or Antagonist Activities of 2,2,2-TEMPS on hmGlu3, hmGlu5, and hmGlu7 Receptor Using Functional Assays

\begin{tabular}{|c|c|c|c|}
\hline Receptor & Assay & Assay mode & Effect $(\mu M)$ \\
\hline hmGuR3 & {$\left[{ }^{35} \mathrm{~S}\right] \mathrm{GTP} \gamma \mathrm{S}$} & $\begin{array}{l}\text { Potentiator } \\
\text { Agonist } \\
\text { Antagonist }\end{array}$ & $\begin{array}{l}\text { n.e. at } 10 \\
\text { n.e. at } 10 \\
\text { n.e. at } 10\end{array}$ \\
\hline hmGuR5 & $\mathrm{Ca}^{2+}$ & $\begin{array}{l}\text { Potentiator } \\
\text { Agonist } \\
\text { Antagonist }\end{array}$ & $\begin{array}{l}\text { n.e. at } 3 \\
\text { n.e. at } 3 \\
\text { n.e. at } 3\end{array}$ \\
\hline hmGuR7 & $\mathrm{Ca}^{2+}$ & $\begin{array}{l}\text { Potentiator } \\
\text { Agonist } \\
\text { Antagonist }\end{array}$ & $\begin{array}{l}\text { n.e. at } 3 \\
\text { n.e at } 3 \\
\text { n.e. at } 3\end{array}$ \\
\hline
\end{tabular}

The antagonist effect of 2,2,2-TEMPS was tested against a submaximal concentration of glutamate as described in Materials and methods. Summary data are calculated from three individual experiments performed in triplicate. n.e. $=$ no effect at concentrations up to 3 or $10 \mu \mathrm{M}$.

receptor agonists (Johnson et al, 2002). Using a functional binding assay, we demonstrated that 2,2,2-TEMPS alone does not alter $\left[{ }^{35} \mathrm{~S}\right] \mathrm{GTP} \gamma \mathrm{S}$ binding in membranes prepared from rat brain or from cells stably expressing hmGlu2 receptors, although 2,2,2-TEMPS did markedly enhance glutamate-induced $\left[{ }^{35} \mathrm{~S}\right] \mathrm{GTP} \gamma \mathrm{S}$ binding. These effects are similar to those reported on mGlu1 and $\mathrm{GABA}_{\mathrm{B}(\mathrm{bb} / 2 \mathrm{~A})}$ receptors with Ro 67-7476 (Knoflach et al, 2001) and CGP7930 (Urwyler et al, 2001), respectively. This positive modulator effect observed with 2,2,2-TEMPS is highly selective for hmGlu2 receptors, since there was a complete absence of any modulatory activity on glutamate-induced $\left[{ }^{35} \mathrm{~S}\right] \mathrm{GTP} \gamma \mathrm{S}$ binding or $\mathrm{Ca}^{2+}$ response in cells stably expressing hmGlu3, hmGlu5, and hmGlu7 receptors. In the presence of 2,2,2-TEMPS, the potency of glutamate was increased approximately two-fold with no change in the maximal response. This change in the potency might reflect a change in the affinity of the receptor for glutamate. A similar effect was observed with Ro 67-7476, which increases the affinity of $\left[{ }^{3} \mathrm{H}\right]$ quisqualate for recombinant mGlu1 receptors without having any effect on the $B_{\max }$. Also, the $\mathrm{GABA}_{\mathrm{B}}$ positive allosteric modulator CGP7930 enhances the binding of the GABA $A_{b}$ agonist $\left[{ }^{3} \mathrm{H}\right] \mathrm{APPA}$ in rat brain membranes via an increase in the affinity (three-fold decrease of the $K_{\mathrm{d}}$ ) without affecting the number of binding sites $\left(B_{\max }\right)$ (Urwyler et al, 2001). 2,2,2-TEMPS was not only a positive modulator at recombinant human mGlu2 receptors but was also effective at increasing $\left[{ }^{35} \mathrm{~S}\right] \mathrm{GTP} \gamma \mathrm{S}$ binding to native rat brain mGlu2 receptors. When tested in vivo, 2,2,2-TEMPS reduced ketamine-evoked NE release by approximately $50 \%$. This effect was reversed by the selective mGlu2/3 receptor antagonist LY341495. It seems, therefore, that mGlu2 receptor stimulation is sufficient to reduce the $\mathrm{NE}$ response to a ketamine challenge. From these and previous experiments (Lorrain et al, 2003), we suggest that mGlu2 receptor modulation may be occurring at the level of the mPFC.

\section{Clinical Implications}

Our primary interest for conducting the current set of experiments was to further establish a potential therapeutic 
Table 3 Effect of 2,2,2-TEMPS on Glutamate-Evoked $\left[{ }^{35} \mathrm{~S}\right] \mathrm{GTP} \gamma \mathrm{S}$ Stimulation at Human mGlu2 and mGlu3 Receptors

\begin{tabular}{|c|c|c|c|c|}
\hline Agonist & \multicolumn{2}{|c|}{ hmGlu2 } & \multicolumn{2}{|c|}{ hmGlu3 } \\
\hline $\begin{array}{l}\text { Glutamate } \\
+2,2,2 \text {-TEMPS }\end{array}$ & $\begin{array}{l}7700(7200-81000) \\
3000(2950-3100)\end{array}$ & $\begin{array}{c}98.14 \pm 1.5 \\
109.67 \pm 0.65\end{array}$ & $\begin{array}{l}162(144-178) \\
200(155-263)\end{array}$ & $\begin{array}{c}100.95 \pm 1.7 \\
91 \pm 3\end{array}$ \\
\hline
\end{tabular}

link between mGlu2 receptor ligands and schizophrenia. As ketamine (in humans) causes symptoms similar to schizophrenia (Javitt and Zukin, 1991; Tamminga et al, 1995), we reason that identifying its CNS effects and then reversing these effects may prove useful in the development of novel antipsychotic drugs. Although much focus has been ascribed to DA regarding the pathophysiology of schizophrenia, noradrenergic systems may also contribute to this illness. As outlined in the introduction, high NE levels have been observed in the cerebral spinal fluid and plasma of drug-free patients (Lake et al, 1980; Breier et al, 1990; van Kammen et al, 1990). Likewise, post-mortem analysis revealed elevated NE in brain tissue taken from schizophrenic patients (Farley et al, 1978; Crow et al, 1979). Together with our current data, it seems reasonable to suggest that a mixed mGlu2/3 receptor agonist or a selective mGlu2 receptor agonist/potentiator may reduce NE neurotransmission and thus provide some benefit in treating the symptoms associated with schizophrenia.

Modulating NE release may also have important implications in anxiety-related behaviors as well as in the expression of opiate withdrawal. It is well established that novel and stressful stimuli to an awake rat activate the LC and increase the release of $\mathrm{NE}$ in forebrain regions (Bremner et al, 1996b). Additionally, administration of $\alpha 2$ antagonists increases LC firing (Rasmussen and Jacobs, 1986) and increases anxiety-like behaviors (Redmond and Huang, 1979). Agents which decrease LC firing, such as opiates, benzodiazepines, (Drugan et al, 1984; Rasmussen and Jacobs, 1986; Tanaka et al, 1990), and clonidine (Aghajanian, 1978; Aghajanian and VanderMaelen, 1982), on the other hand, decrease anxiety behaviors. In humans trials, clonidine has been shown to be effective in some, but not all, patients with panic disorder (Bremner et al, 1996a). Likewise, Levine et al (2002) recently reported anxiolytic effects of LY354740 in human panic patients undergoing $\mathrm{CO}_{2}$-induced panic. In a manner consistent with anxiety, behaviors associated with morphine withdrawal appear to be, at least in part, a reflection of LC activity (Aghajanian, 1978; Rasmussen et al, 1990; Maldonado and Koob, 1993). As mentioned above, previous experimentation has revealed an effect of the group II mGlu receptor agonist LY354740 on reducing morphine-withdrawal-induced activation of LC neurons and many of morphine withdrawal symptoms (Vandergriff and Rasmussen, 1999).

In conclusion, the mixed mGlu2/3 receptor agonist LY379268 and the mGluR2 selective positive modulator 2,2,2-TEMPS suppressed ketamine-evoked VHipp NE release. This effect appears to be mediated, at least in part, through activation of mGlu receptors located within the mPFC. These results demonstrate a novel means to suppress noradrenergic neurotransmission (ie by activating mGlu2 receptors) and may, therefore, have important implications for neuropsychiatric disorders in which aberrant activation of the noradrenergic system is thought to be involved (eg schizophrenia, anxiety/panic, morphine/heroin drug withdrawal).

\section{ACKNOWLEDGEMENTS}

We thank John Nikpur for his excellent surgical support and Jim Hanlon, Alison Rush, and Jammieson Pires for their efforts in counter-screening.

\section{REFERENCES}

Adams BW, Moghaddam B (2001). Effect of clozapine, haloperidol, or M100907 on phencyclidine-activated glutamate efflux in the prefrontal cortex. Biol Psychiatry 50: 750-757.

Aghajanian GK (1978). Tolerance of locus coeruleus neurones to morphine and suppression of withdrawal response by clonidine. Nature 276: 186-188.

Aghajanian GK, VanderMaelen CP (1982). alpha 2-adrenoceptormediated hyperpolarization of locus coeruleus neurons: intracellular studies in vivo. Science 215: 1394-1396.

Bakshi VP, Geyer MA (1997). Phencyclidine-induced deficits in prepulse inhibition of startle are blocked by prazosin, an alpha- 1 noradrenergic antagonist. J Pharmacol Exp Ther 283: 666-674.

Bakshi VP, Geyer MA (1999). Alpha-1-adrenergic receptors mediate sensorimotor gating deficits produced by intracerebral dizocilpine administration in rats. Neuroscience 92: 113-121.

Baldessarini RJ, Huston-Lyons D, Campbell A, Marsh E, Cohen BM (1992). Do central antiadrenergic actions contribute to the atypical properties of clozapine? Br J Psychiatry 17(Suppl): $12-16$.

Breier A, Wolkowitz OM, Roy A, Potter WZ, Pickar D (1990). Plasma norepinephrine in chronic schizophrenia. Am J Psychiatry 147: 1467-1470.

Bremner JD, Krystal JH, Southwick SM, Charney DS (1996a). Noradrenergic mechanisms in stress and anxiety: II. Clinical studies. Synapse 23: 39-51.

Bremner JD, Krystal JH, Southwick SM, Charney DS (1996b). Noradrenergic mechanisms in stress and anxiety: I. Preclinical studies. Synapse 23: 28-38.

Buchanan SL, Thompson RH, Maxwell BL, Powell DA (1994). Efferent connections of the medial prefrontal cortex in the rabbit. Exp Brain Res 100: 469-483.

Cartmell J, Monn JA, Schoepp DD (1999). The metabotropic glutamate $2 / 3$ receptor agonists LY354740 and LY379268 selectively attenuate phencyclidine versus D-amphetamine motor behaviors in rats. J Pharmacol Exp Ther 291: 161-170.

Crow TJ, Baker HF, Cross AJ, Joseph MH, Lofthouse R, Longden A et al (1979). Monoamine mechanisms in chronic schizophrenia: post-mortem neurochemical findings. $\mathrm{Br} J$ Psychiatry 134: 249-256. 
Drugan RC, Ryan SM, Minor TR, Maier SF (1984). Librium prevents the analgesia and shuttlebox escape deficit typically observed following inescapable shock. Pharmacol Biochem Behav 21: 749-754.

Dube GR, Marshall KC (1997). Modulation of excitatory synaptic transmission in locus coeruleus by multiple presynaptic metabotropic glutamate receptors. Neuroscience 80: 511-521.

Duncan GE, Miyamoto S, Leipzig JN, Lieberman JA (1999). Comparison of brain metabolic activity patterns induced by ketamine, MK-801 and amphetamine in rats: support for NMDA receptor involvement in responses to subanesthetic dose of ketamine. Brain Res 843: 171-183.

Farley IJ, Price KS, McCullough E, Deck JH, Hordynski W, Hornykiewicz O (1978). Norepinephrine in chronic paranoid schizophrenia: above-normal levels in limbic forebrain. Science 200: 456-458.

Flicker C, Geyer MA (1982). The hippocampus as a possible site of action for increased locomotion during intracerebral infusions of norepinephrine. Behav Neural Biol 34: 421-426.

Javitt DC, Zukin SR (1991). Recent advances in the phencyclidine model of schizophrenia. Am J Psychiatry 148: 1301-1308.

Johnson M, Baez M, Britton T, Jagdam Jr GE, Johnson K, Johnson B et al (2002). Subtype-selective positive allosteric modulators of the metabotropic glutamate 2 receptor: in vitro and in vivo characterization of novel mGlu2 potentiators. Neuropharmacology 43: 291.

Kubota T, Hirota K, Yoshida H, Takahashi S, Anzawa N, Ohkawa H et al (1999a). Effects of sedatives on noradrenaline release from the medial prefrontal cortex in rats. Psychopharmacology (Berl) 146: 335-338.

Kubota T, Hirota K, Yoshida H, Takahashi S, Ohkawa H, Anzawa N et al (1999b). Inhibitory effect of clonidine on ketamine-induced norepinephrine release from the medial prefrontal cortex in rats. Br J Anaesth 83: 945-947.

Knoflach F, Woltering T, Adam G, Mutel V, Kemp JA (2001). Pharmacological properties of native metabotropic glutamate receptors in freshly dissociated Golgi cells of the rat cerebellum. Neuropharmacology 40: 163-169.

Lake CR, Sternberg DE, van Kammen DP, Ballenger JC, Ziegler MG, Post RM et al (1980). Schizophrenia: elevated cerebrospinal fluid norepinephrine. Science 207: 331-333.

Levine LR, Gaydos B, Sheehan D (2002). The mGlu 2/3 receptor agonist, LY354740 reduces panic anxiety induced by $\mathrm{CO}_{2}$ challenge in patients diagnosed with panic disorder. Neuropharmacology 43: 294.

Lindefors N, Barati S, O'Connor WT (1997). Differential effects of single and repeated ketamine administration on dopamine, serotonin and GABA transmission in rat medial prefrontal cortex. Brain Res 759: 205-212.

Lorrain DS, Baccei CS, Bristow LJ, Anderson JJ, Varney MA (2003). Effects of ketamine and NMDA on glutamate and dopamine release in the rat prefrontal cortex: modulation by a group II selective mGluR agonist LY379268. Neuroscience 117: 697-706.

Maldonado R, Koob GF (1993). Destruction of the locus coeruleus decreases physical signs of opiate withdrawal. Brain Res 605: $128-138$

Marek GJ, Wright RA, Gewirtz JC, Schoepp DD (2001). A major role for thalamocortical afferents in serotonergic hallucinogen receptor function in the rat neocortex. Neuroscience 105: 379-392.

Marek GJ, Wright RA, Schoepp DD, Monn JA, Aghajanian GK (2000). Physiological antagonism between 5-hydroxytryptamine(2A) and group II metabotropic glutamate receptors in prefrontal cortex. J Pharmacol Exp Ther 292: 76-87.

Martin P, Carlsson ML, Hjorth S (1998). Systemic PCP treatment elevates brain extracellular 5-HT: a microdialysis study in awake rats. Neuroreport 9: 2985-2988.
Mathe JM, Nomikos GG, Hildebrand BE, Hertel P, Svensson TH (1996). Prazosin inhibits MK-801-induced hyperlocomotion and dopamine release in the nucleus accumbens. Eur J Pharmacol 309: $1-11$

Moghaddam B, Adams BW (1998). Reversal of phencyclidine effects by a group II metabotropic glutamate receptor agonist in rats. Science 281: 1349-1352.

Moghaddam B, Adams B, Verma A, Daly D (1997). Activation of glutamatergic neurotransmission by ketamine: a novel step in the pathway from NMDA receptor blockade to dopaminergic and cognitive disruptions associated with the prefrontal cortex. $J$ Neurosci 17: 2921-2927.

Monn JA, Valli MJ, Massey SM, Hansen MM, Kress TJ, Wepsiec JP et al (1999). Synthesis, pharmacological characterization, and molecular modeling of heterobicyclic amino acids related to (+)2-aminobicyclo[3.1.0] hexane-2,6-dicarboxylic acid (LY354740): identification of two new potent, selective, and systemically active agonists for group II metabotropic glutamate receptors. $J$ Med Chem 42: 1027-1040.

Paxinos G, Watson C (1998). The Rat Brain in Stereotaxic Coordinates, 4th edn Academic Press: Sydney.

Rasmussen K, Jacobs BL (1986). Single unit activity of locus coeruleus neurons in the freely moving cat. II. Conditioning and pharmacologic studies. Brain Res 371: 335-344.

Rasmussen K, Beitner-Johnson DB, Krystal JH, Aghajanian GK, Nestler EJ (1990). Opiate withdrawal and the rat locus coeruleus: behavioral, electrophysiological, and biochemical correlates. $J$ Neurosci 10: 2308-2317.

Redmond Jr DE, Huang YH (1979). Current concepts. II. New evidence for a locus coeruleus-norepinephrine connection with anxiety. Life Sci 25: 2149-2162.

Schaffhauser H, Richards JG, Cartmell J, Chaboz S, Kemp JA, Klingelschmidt A et al (1998). In vitro binding characteristics of a new selective group II metabotropic glutamate receptor radioligand, $\left[{ }^{3} \mathrm{H}\right] \mathrm{LY} 354740$, in rat brain. Mol Pharmacol 53: 228-233.

Schoepp DD, Johnson BG, Wright RA, Salhoff CR, Mayne NG, Wu S et al (1997). LY354740 is a potent and highly selective group II metabotropic glutamate receptor agonist in cells expressing human glutamate receptors. Neuropharmacology 36: $1-11$.

Schotte A, Janssen PF, Gommeren W, Luyten WH, Van Gompel P, Lesage AS et al (1996). Risperidone compared with new and reference antipsychotic drugs: in vitro and in vivo receptor binding. Psychopharmacology (Berl) 124: 57-73.

Segal DS, Mandell AJ (1970). Behavioral activation of rats during intraventricular infusion of norepinephrine. Proc Natl Acad Sci USA 66: 289-293.

Svensson TH (2000). Dysfunctional brain dopamine systems induced by psychotomimetic NMDA-receptor antagonists and the effects of antipsychotic drugs. Brain Res Brain Res Rev 31: 320-329.

Takagishi M, Chiba T (1991). Efferent projections of the infralimbic (area 25) region of the medial prefrontal cortex in the rat: an anterograde tracer PHA-L study. Brain Res 566: 2639.

Tamminga CA, Holcomb HH, Gao XM, Lahti AC (1995). Glutamate pharmacology and the treatment of schizophrenia: current status and future directions. Int Clin Psychopharmacol 10(Suppl 3): 29-37.

Tanaka M, Tsuda A, Yokoo H, Yoshida M, Ida Y, Nishimura H (1990). Involvement of the brain noradrenaline system in emotional changes caused by stress in rats. Ann NY Acad Sci 597: 159-174.

Urwyler S, Mosbacher J, Lingenhoehl K, Heid J, Hofstetter K, Froestl W et al (2001). Positive allosteric modulation of native and recombinant gamma-aminobutyric acid(B) receptors by 2,6-Di-tert-butyl-4-(3-hydroxy-2,2-dimethyl-propyl)- 
phenol (CGP7930) and its aldehyde analog CGP13501. Mol Pharmacol 60: 963-971.

Van Kammen DP, Peters J, Yao J, van Kammen WB, Neylan T, Shaw D et al (1990). Norepinephrine in acute exacerbations of chronic schizophrenia. Negative symptoms revisited. Arch Gen Psychiatry 47: 161-168.

Vandergriff J, Rasmussen K (1999). The selective mGlu2/3 receptor agonist LY354740 attenuates morphine-withdrawal-induced activation of locus coeruleus neurons and behavioral signs of morphine withdrawal. Neuropharmacology 38: 217-222.
Varney MA, Cosford ND, Jachec C, Rao SP, Sacaan A, Lin FF et al (1999). SIB-1757 and SIB-1893: selective, noncompetitive antagonists of metabotropic glutamate receptor type 5.J Pharmacol Exp Ther 290: 170-181.

Yonezawa Y, Kuroki T, Kawahara T, Tashiro N, Uchimura H (1998). Involvement of gamma-aminobutyric acid neurotransmission in phencyclidine-induced dopamine release in the medial prefrontal cortex. Eur J Pharmacol 341: 45-56. 